\title{
Pengarub Penggunaan Metode Permainan Kartu Bilangan \\ PENGARUH PENGGUNAAN METODE PERMAINAN KARTU BILANGAN TERHADAP MOTIVASI DAN HASIL BELAJAR SISWA MATERI PECAHAN
}

\author{
Dukan Jauhari Faruq \\ Dosen Prodi Pendidikan Guru Madrasah Ibtida'iyah \\ Institut Agama Islam Al-Falah As-Sunniyyah (INAIFAS) Kencong Jember \\ e-mail: djauharifaruq@gmail.com
}

\begin{abstract}
This study aims to determine the effect of the use of the number card playing method on student motivation and learning outcomes in fraction material in class IV SD NU 03 Nurul Huda Wuluhan Jember. The research method used was a quasi-experimental study with a total of 20 experimental and control class students. Data collection techniques are using pretest and posttest. Analysis of the data used was the $\mathrm{T}$ test. The results of the data analysis with the $\mathrm{T}$ test at the 95\% confidence level showed that the learning outcomes of the experimental class students who used the number card playing method were better than students in the control class who did not use the number card playing method. From the results of the above analysis the researcher draws the conclusion that the learning outcomes of students who use the number card game method program are higher than students who do not use the number card game method. So the number card game method can be used as an alternative learning media that can increase student motivation and learning outcomes.
\end{abstract}

Keywords: Game Method, Number Cards, Learning Outcomes.

\begin{abstract}
Abstrak
Penelitian ini bertujuan untuk mengetahui pengaruh penggunaan metode permainan kartu bilangan terhadap motivasi dan hasil belajar siswa pada materi pecahan di kelas IV SD NU 03 Nurul Huda Wuluhan Jember. Metode penelitian yang digunakan adalah penelitian eksperimen kuasi dengan jumlah siswa kelas eksperimen dan kontrol masing-masing 20 siswa. Teknik pengumpulan data yaitu dengan menggunakan pretes dan postes. Analisis data yang digunakan adalah uji T. Hasil analisis data dengan uji T pada taraf kepercayaan 95\% menunjukkan bahwa hasil belajar siswa kelas eksperimen yang menggunakan metode permainan kartu bilangan lebih baik dibandingkan siswa di kelas kontrol yang tidak menggunakan metode permainan kartu bilangan. Dari hasil analisis di atas peneliti menarik kesimpulan bahwa hasil belajar siswa yang menggunakan program metode permainan kartu bilangan lebih tinggi daripada siswa yang tidak menggunakan metode permainan kartu bilangan. Jadi metode permainan kartu bilangan dapat digunakan sebagai alternatif media pembelajaran yang dapat meningkatkan motivasi dan hasil belajar siswa.
\end{abstract}

Kata kunci: Metode Permainan, Kartu Bilangan, Hasil Belajar.

Vol. ㄱ. No. Q2. Iktober 2019

Jurnal Auladuna $\mid 83$ 


\section{Dukan Jaubari Faruq}

\section{Pendahuluan}

Matematika merupakan mata pelajaran yang bersifat abstrak, sehingga dituntut kemampuan guru untuk dapat mengupayakan metode yang tepat sesuai dengan tingkat perkembangan mental siswa (Hudoyo, 2005). Sifatnya yang abstrak dapat menjadi penyebab kesulitan siswa dalam mempelajari matematika terutama materi pecahan.

Ainurrahman (2009) menyatakan bahwa pembelajaran ialah adanya proses belajar pada diri seseorang dan di dalam dirinya terjadi suatu perubahan dari tidak tahu menjadi tahu, dari tidak mengerti menjadi mengerti dan sebagainya serta hasil belajar dapat dilihat secara langsung - Sedangkan Sagala (2010) berpendapat bahwa pembelajaran ialah membelajarkan siswa menggunakan asas pendidikan maupun teori belajar merupakan penentu utama keberhasilan pendidikan. Dalam kegiatan pembelajaran tujuan yang ingin dicapai telah ditentukan sebelumnya, anak yang dikatakan berhasil adalah mereka yang dapat mencapai tujuan pelajaran yang telah ditentutan sebelum proses belajar berlangsung.

Metode adalah cara yang digunakan untuk mengimplementasikan rencana yang sudah disusun dalam kegiatan nyata agar tujuan yang telah disusun tercapai secara optimal. (Sanjaya, 2011) Ini berarti metode digunakan untuk merealisasikan strategi yang telah ditetapkan. Dengan demikian dalam rangkaian sistem pembelajaran memegang peran yang sangat penting. keberhasilan implementasi strategi pembelajaran sangat tergantung pada cara guru menggunakan metode pembelajaran, karena suatu strategi pembelajaran hanya mungkin dapat diimplementasikan melalui penggunaan metode pembelajaran.

Dari pengertian di atas dapat disimpulkan bahwa metode berhubungan dengan cara yang memungkinkan peserta didik memperoleh kemudahan dalam rangka mempelajari bahan ajar yang disampaikan oleh guru. Sehingga ketepatgunaan dalam memilih metode sangat berpeluang bagi terciptanya kondisi pembelajaran yang kondusif, menyenangkan, sehingga kegiatan pembelajaran (instructional activities) dapat berlangsung secara efektif dan efisien dalam memfasilitasi peserta didik untuk dapat meraih hasil belajar sesuai yang diharapkan.

Siswa dalam belajar juga membutuhkan motivasi yaitu suatu dorongan atau kekuatan yang menyebabkan siswa mempunyai keinginan untuk melakukan kegiatan belajar. Guru memiliki peranan penting dalam menumbuhkan motivasi belajar siswa. Guru dapat menciptakan pembelajaran yang menarik sehingga dapat menumbuhkan motivasi belajar siswa 
dan media pembelajaran adalah salah satu alat yang dapat digunakan untuk membantu guru menciptakan pembelajaran yang menarik.

Dari hasil pengamatan yang peneliti lakukan di SD NU 03 Nurul Huda Kecamatan Wuluhan masalah yang dihadapi adalah prestasi belajar matematika siswa kelas IV belum seperti yang diharapkan. Rendahnya pemahaman siswa diakibatkan siswa sendiri yang kurang tertarik terhadap pembelajaran yang disampaikan oleh guru. Metode yang digunakan lebih banyak menggunakan metode ceramah tanpa didukung metode pembelajaran yang lain dan tanpa alat bantu mengajar yang bervariasi. Hal tersebut mengakibatkan pembelajaran yang monoton dan kurang melibatkan siswa secara aktif sehingga siswa tidak tertarik terhadap pembelajaran yang disampaikan oleh guru dan mengakibatkan rendahnya hasil belajar siswa.

Aman (1985) berpendapat bahwa permainan adalah cara penyajian bahan pengajaran di mana siswa melakukan untuk memperoleh atau menemukan pengertian konsep tertentu. Permainan dalam arti permainan pendidikan, siswa melakukan kegiatan (permainan) dalam kerangka proses belajar mengajar. Sebagai metode mengajar, metode permainan dapat dilakukan secara individual atau kelompok. Permainan dimaksud untuk membangun suasana belajar yang dinamis, penuh semangat, dan antusiasme. Sebaiknya permainan digunakan sebagai bagian dari proses belajar, bukan hanya untuk sekedar mengisi waktu luang. Permainan sebaiknya dirancang menjadi suatu aksi atau kejadian yang dialami sendiri oleh siswa, kemudian ditarik dalam proses refleksi untuk menjadi kesan yang mendalam.

Tujuan penggunaan metode permainan adalah untuk mengajarkan pengertian (konsep), menanamkan nilai, dan memecahkan masalah. Sedangkan manfaat metode permainan yaitu membangkitkan minat siswa, mengembangkan rasa kerjasama siswa, dan mengembangkan kreativitas siswa.

Dalam penelitian ini peneliti menggunakan kartu bilangan untuk mengajarkan materi tentang pecahan. Kartu bilangan yang dimaksud adalah kartu yang terbuat dari kertas dan berbentuk seperti kartu domino. Di sini, kartu domino digunakan sebagai media pembelajaran dan tidak digunakan untuk berjudi. Kartu bilangan memiliki manfaat untuk mengkonkritkan ide-ide abstrak, memberikan perangsang yang sama, menyamakan pengalaman dan menimbulkan persepsi yang sama, mengarahkan perhatian siswa pada satu titik fokus, memungkinkan terjadinya interaksi langsung antara guru dengan siswa, model dan warna kartu 


\section{Dukan Jaubari Faruq}

bilangan yang dibuat menarik merupakan daya tarik tersendiri bagi siswa sehingga menarik minat siswa dan dapat digunakan untuk permainan.

Kartu domino merupakan suatu media pembelajaran yang dapat digunakan untuk menarik minat siswa dalam pembelajaran matematika. Selain itu kartu domino juga digunakan untuk menghafal fakta dasar penjumlahan, pengurangan, perkalian dan pembagian serta digunakan untuk menghafal bangun-bangun geometri. (Darhim, 2001)

Dalam pembelajaran pecahan di sini menggunakan 36 kartu yang berfungsi mengubah pecahan biasa menjadi pecahan desimal dan sebaliknya. Contoh kartu sebagai berikut ini:

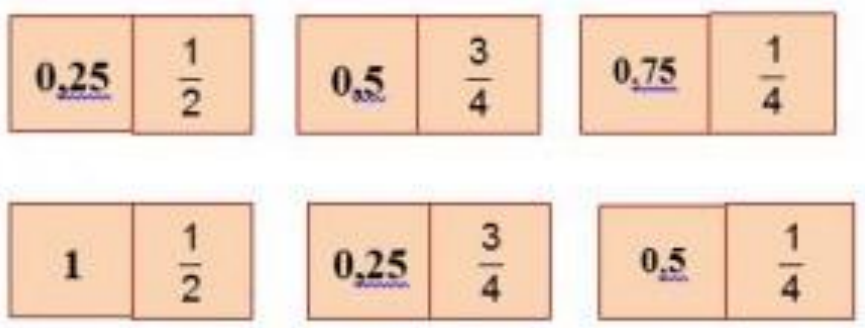

Gambar 1. Tampilan kartu bilangan

Setiap kartu mempunyai 2 bagian yang berbeda yaitu 1 bagian berisi pecahan desimal dan 1 bagian berisi pecahan biasa. Adapun cara pembuatannya yaitu tuliskan bentuk pecahan desimal pada bagian kiri dan bentuk pecahan yang senilai dengan bentuk pecahan desimal tersebut pada bagian sebelah kanan dengan cara pengacakan sebagai berikut:

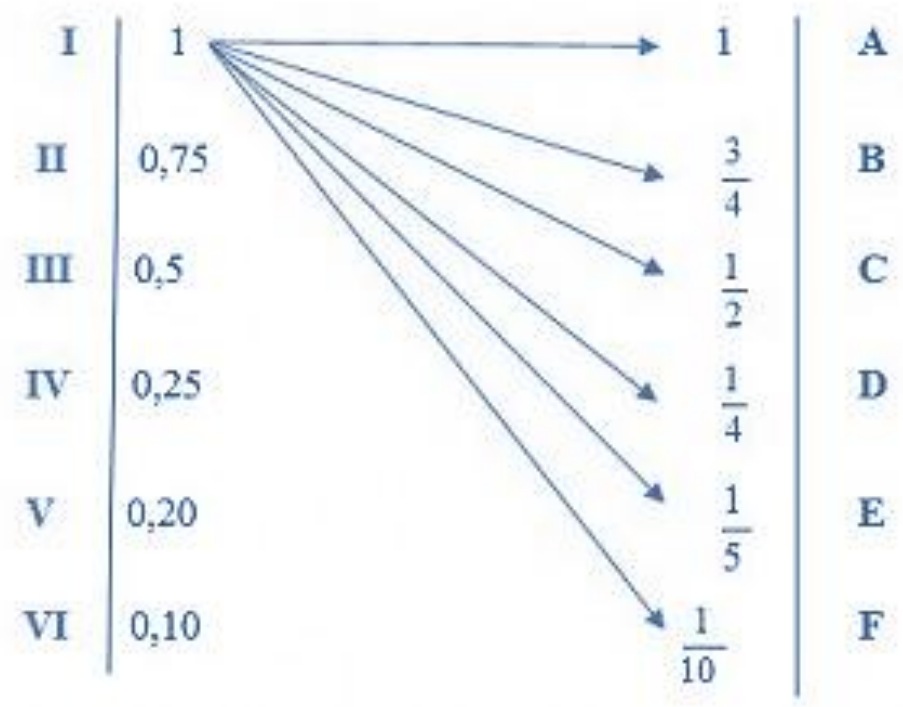

Gambar 2. Cara pengacakan pembuatan kartu bilangan 
Selanjutnya dibentuk pasang sebagai berikut:

(I, A), (I, B), (1, C), .., (I, F)

(II, A), (II, B), (II, C), ..., (II, F) ....... dan seterusnya sampai

(VI, A), (VI, B), (VI, C), .., (VI, F)

Sehingga banyaknya kartu ada 6 × $6=36$ kartu

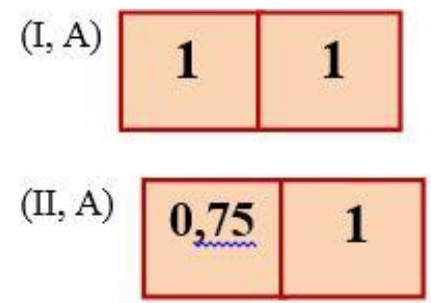

Gambar 3. Contoh hasil pengacakan

Beberapa penelitian sebelumnya telah membuktikan bahwa penggunaan metode permainan kartu bilangan telah memberikan pengaruh yang positif terhadap hasil belajar siswa (Deni Dwiana, dkk. 2011), permainan kartu bilangan dapat meningkatkan pemahaman siswa terhadap konsep pecahan sehingga permainan kartu bilangan mampu meningkatakan kemampuan pemahaman dan visual thinking siswa SD NU 03 Nurul Huda.

Hasil penelitian Zaelani (2011) menunjukkan bahwa metode permainan kartu bilangan dapat mengatasi kesulitan siswa dalam mempelajari pecahan terutama dalam merubah pecahan biasa menjadi pecahan desimal atau sebaliknya merubah pecahan desimal menjadi pecahan biasa.

Berdasarkan uraian di atas, maka masalah dalam penelitian ini adalah apakah penggunaan metode permainan kartu bilangan dapat meningkatkan hasil belajar siswa pada pembelajaran Matematika tentang pecahan siswa kelas IV?

Penelitian ini bertujuan untuk meningkatkan hasil belajar siswa pada pembelajaran Matematika tentang pecahan pada siswa kelas IV melalui penggunaan metode permainan kartu bilangan.

\section{Metode Penelitian}

Vol. ㄴ. №. 02. Oktober 2019

Jurnal Auladuna | 87 


\section{Dukan Jaubari Faruq}

Jenis penelitian yang digunakan adalah Eksperimen kuasi, peneliti ingin membandingkan hasil belajar siswa kelas eksperimen dan kelas kontrol. Kelas eksperimen adalah kelas yang menggunakan metode permainan kartu bilangan sebagai media pembelajaran yaitu kelas IV A sedangkan kelas kontrol adalah kelas yang tidak menggunakan metode permainan kartu bilangan yaitu kelas IV B. Jumlah siswa dari masing-masing kelas adalah 20 siswa. Penelitian dilaksanakan pada tanggal 7 Oktober 2019 sampai dengan 18 Oktober 2019.

Dalam penelitin ini kedudukan peneliti hanya sebagai disigner konsep yang kemudian ditawarkan kepada guru pada kelas yang bersangkutan, sehingga dalam penelitian ini peneliti hanya mengamati proses belajar mengajar dengan konsep yang telah dibuat dan dipraktekkan oleh masing-masing guru kelas yang bersangkutan. Hal ini bertujuan lingkungan belajar tetap sama namun metode dan konsepnya berbeda sehingga bisa diketahui perubahan motivasi dan hasil belajar bukan karena pengajarnya tetapi karena metode dan konsep yang dibawanya.

Metode pengumpulan data yang digunakan adalah tes. Tes dalam penelitian ini berupa pretes dan postes. Pretes diberikan sebelum pembelajaran tentang pecahan dengan tujuan untuk melihat kemampuan awal siswa kelas eksperimen dan kelas kontrol. Postes diberikan setelah siswa menyelesaikan pembelajaran tentang pecahan, data postes digunakan untuk mengetahui hasil belajar siswa. Data penelitian yang telah diperoleh kemudian dianalisis dengan menggunakan uji t.

Pembelajaran di kelas kontrol dilaksanakan secara konvensional yaitu tidak menggunakan metode permainan kartu bilangan, media pembelajaran yang digunakan hanya papan tulis dan spidol. Sedangkan pembelajaran di kelas eksperimen menggunakan metode permainan kartu bilangan. Permainan kartu pecahan ini digunakan secara berkelompok. Tiap kelompok terdiri dari 4 atau 6 anak. Pada saat bermain, 1 set kartu yang akan digunakan dikocok terlebih dahulu. Kemudian kartu-kartu tersebut dibagikan kepada semua pemain yang mengikuti, kemudian pemasangan kartu diatur secara bergiliran untuk semua pemain, setiap pemain harus memasangkan kartu yang bernilai sama antara pecahan desimal dengan pecahan biasa, misalnya pemain harus memasangkan kartu yang mempunyai bagian pecahan desimal senilai dengan $3 / 4$ yaitu 0,75 atau bisa pula pemain memasangkan kartu yang mempunyai angka pecahan biasa senilai dengan 0,5 yaitu $1 / 2$. 
Pengaruh Penggunaan Metode Permainan Kartu Bilangan

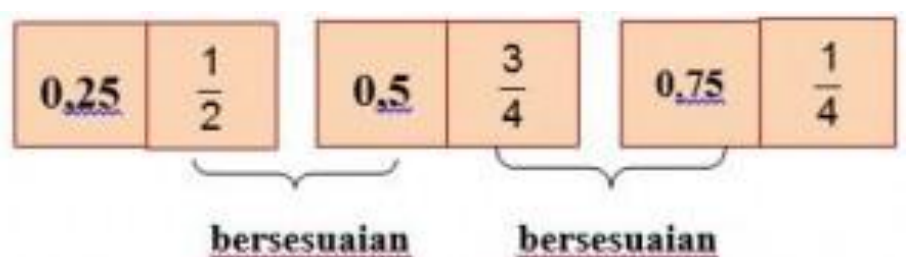

Gambar 4. Contoh pemasangan kartu

Ada dua cara untuk membagikan kartu kepada pemain namun intinya sama saja, pada kelompok pertama dan kedua siswa diminta membagi semua kartu yang ada kepada semua pemain sehingga masing-masing pemain mendapatkan jumlah kartu yang sama. Sedangkan pada kelompok lainnya siswa diminta membagi beberapa kartu pada pemain sedangkan sisanya ditumpuk terbalik, sehingga cara ini masih memungkinkan pemain mengambil kartu sisa tersebut bila pada gilirannya pemain tidak mempunyai kartu yang sesuai untuk dipasangkan.

Pemain dinyatakan sebagai pemenang apabila kartunya telah habis sedangkan pemain lain tetap melanjutkan permainan, atau sisa kartu miliknya paling sedikit bila bila permainan terhenti karena tidak ada lagi kartu-kartu milik pemain yang cocok untuk dipasangkan. Urutan pemenang ditentukan oleh banyaknya kartu yang masih dipegang oleh masing-masing pemain.

Penelitian ini dilakukan melalui tiga tahap yaitu tahap persiapan, tahap pelaksanaan, dan tahap analisis data. Pada tahap persiapan, peneliti (1) melakukan observasi atau pra riset, (2) menyiapkan perangkat pembelajaran berupa Rencana Pelaksanaan Pembelajaran (RPP) (3) menyiapkan instrumen penelitian.

Tahap pelaksanaan, antara lain: (1) menentukan kelas eksperimen dan kelas kontrol, (2) memberikan tes awal atau pretest, (3) memberikan pembelajaran dengan metode permainan kartu bilangan pada kelas eksperimen dan pembelajaran konvesional pada kelas kontrol, dan (4) memberikan tes akhir atau postest.

Pada tahap akhir yaitu analisis data yang meliputi: (1) mengolah data yang diperoleh dengan uji statistik yang sesuai untuk menjawab hipotesis penelitian, (2) menganalisis hasil pengolahan data, dan (3) membuat kesimpulan.

\section{Hasil dan Pembahasan}

Data hasil penelitian ini berupa nilai pretes dan postes. Data dianalisis untuk mengetahui perbedaan hasil belajar siswa kelas eksperimen dan kelas kontrol.

1. Hasil Pretes

Vol. ㄱ. No. Q2. Iktober 2019

Jurnal Auladuna | 89 


\section{Dukan Jaubari Faruq}

Sebelum pembelajaran siswa diberikan pretes dengan tujuan untuk mengetahui kemampuan awal siswa. hasil pretes yang diperoleh siswa kelas eksperimen dan kelas kontrol sebagai berikut:

Tabel 1. Data Pretes

\begin{tabular}{|c|c|c|c|c|}
\hline Kelas & Nilai terendah & Nilai terbesar & Rata-rata & Standar deviasi \\
\hline \hline Eksperimen & 40 & 75 & 63,05 & 8,92 \\
\hline Kontrol & 50 & 90 & 65,9 & 9,85 \\
\hline
\end{tabular}

Berdasarkan Tabel 1 dapat diketahui bahwa nilai rata-rata pretes kelas eksperimen adalah 63,05 dan kelas kontrol adalah 65,9, rata-rata nilai pretes kelas kontrol dianalisis dengan uji $\mathrm{T}$ untuk mengetahui kemampuan awal siswa tidak berbeda secara signifikan. Kesimpulan uji $\mathrm{T}$ rata-rata nilai pretes adalah $\mathrm{H}_{0}$ diterima karena $\mathrm{T}_{\text {hitung }}<\mathrm{T}_{\text {tabel }}$ yaitu $1,52<1,73$, artinya pada tingkat kepercayaan 95\% rata-rata nilai pretes siswa kelas eksperimen dan kelas kontrol tidak berbeda secara signifikan. Dari kesimpulan tersebut dapat dikatakan bahwa kemampuan awal siswa kelas eksperimen dan kelas kontrol tidak berbeda secara signifikan.

2. Hasil Postes

Setelah pembelajaran pecahan, siswa kelas eksperimen dan kontrol diberi postes. Hasil postes bertujuan untuk mengukur hasil belajar siswa tentang materi pecahan. Postes kelas eksperimen dan kelas kontrol dilaksanakan tanggal 16 Oktober 2019.

Tabel 2. Data Postest

\begin{tabular}{|c|c|c|c|c|}
\hline Kelas & Nilai terendah & Nilai terbesar & Rata-rata & Standar deviasi \\
\hline \hline Eksperimen & 65 & 100 & 76,5 & 9,04 \\
\hline Kontrol & 55 & 80 & 68,5 & 7,45 \\
\hline
\end{tabular}

Berdasarkan Tabel 2 di atas dapat diketahui bahwa rata-rata nilai postes kelas eksperimen adalah 76,5 dan kelas kontrol adalah 68,5. Rata-rata nilai postes siswa kelas eksperimen lebih tinggi daripada kelas kontrol. Jika dibandingkan dengan rata-rata nilai pretes dan postes, rata-rata nilai pretes siswa kelas kontrol lebih tinggi daripada kelas 
eksperimen tetapi sebaliknya rata-rata nilai postes siswa kelas eksperimen lebih tinggi daripada kelas kontrol. Dengan melihat hasil pretes dan postes dapat disimpulkan bahwa metode permainan kartu bilangan memiliki pengaruh terhadap hasil belajar siswa.

Nilai postes kelas eksperimen dan kontrol dianalisis dengan menggunakan uji $\mathrm{T}$ untuk menguji hipotesis rata-rata nilai postes. Hasil uji hipotesis yaitu $\mathrm{H}_{0}$ ditolak karena $\mathrm{T}_{\text {hitung }}>\mathrm{T}_{\text {tabel }}$ yaitu 5,27 $>1,73$ artinya pada tingkat kepercayaan 95\% rata-rata nilai postes siswa kelas eksperimen lebih tinggi dari pada kelas kontrol.

Dari hasil uji hipotesis tersebut dapat disimpulkan bahwa hasil belajar siswa yang menggunakan metode permainan kartu bilangan di dalam pembelajaran pecahan lebih baik daripada siswa yang tidak menggunakan metode permainan kartu bilangan. Dengan demikian pembelajaran dengan menggunakan metode permainan kartu bilangan dapat memberikan pengaruh meskipun tidak terlalu signifikan terhadap hasil belajar siswa namun bisa meningkatkan motivasi belajar yang cukup tinggi. Hal tersebut kemungkinan besar disebabkan oleh permainan kartu bilangan dapat menjadi selingan bagi siswa dalam belajar karena disamping mereka belajar mereka juga berkompetisi dengan siswa lain dalam kelompoknya untuk segera memenangkan permainan tersebut dengan segera menghabiskan kartu-kartu yang dipegangnya. Selain itu otak mereka juga harus selalu dipacu aktif untuk melihat, menghitung dan mengingat kartu-kartu yang telah dipasangkan oleh lawan yang kemudian melihat dan menghitung kartu sendiri yang akan dipasangkan dengan kartu yang telah dijatuhkan.

Hasil pengamatan peneliti secara langsung pada proses pembelajaran di kelas eksperimen dan kontrol. Siswa kelas eksperimen lebih banyak yang aktif dalam memainkan kartu bahkan mengulanginya kembali ketika permainan sudah usai. Sedangkan siswa yang berada di kelas kontrol cenderung monoton karena mereka hanya dihadapkan pada hitunganhitungan di atas kertas biasa saja tanpa adanya permainan apapun.

Di samping dari tes hasil belajar siswa, peneliti juga melakukan pengamatan secara langsung selama proses pembelajaran berlangsung. Peneliti melihat siswa di kelas eksperimen lebih aktif daripada siswa di kelas kontrol pada proses pembelajaran. Siswa di kelas eksperimen lebih banyak bertanya,karena mereka tidak ingin kalah dengan siswa yang menjadi lawan di kelompoknya. Siswa kelas eksperimen banyak yang memperhatikan penjelasan dari guru daripada siswa kelas kontrol. Siswa di kelas kontrol tidak mendapatkan suasana pembelajaran 


\section{Dukan Jaubari Faruq}

yang berbeda dari pembelajaran sebelumnya sehingga siswa kurang tertarik dengan pembelajaran materi pecahan.

Secara keseluruhan hasil penelitian ini telah mendukung penelitian sebelumnya yaitu penelitian yang dilakukan Deni Dwiana bahwa penggunaan metode permainan kartu bilangan telah memberikan pengaruh yang positif terhadap hasil belajar siswa(Deni Dwiana, dkk. 2011), permainan kartu bilangan dapat meningkatkan pemahaman siswa terhadap konsep pecahan sehingga permainan kartu bilangan mampu meningkatkan kemampuan pemahaman dan visual thinking siswa SD NU 03 Nurul Huda

Selanjutnya hasil penelitian ini juga sejalan dengan hasil penelitian Zaelani (2011) menunjukkan bahwa metode permainan kartu bilangandapat menguasi kesulitan siswa dalam mempelajari pecahan terutama dalam merubah pecahan biasa menjadi pecahan desimal atau sebaliknya merubah pecahan desimal menjadi pecahan biasa.

\section{Simpulan Dan Saran}

Berdasarkan hasil penelitian pengaruh penggunaan metode permainan kartu bilangan terhadap motivasi dan hasil belajar siswa pada materi pecahan di SD NU 03 Nurul Huda Kecamatan Wuluhan Kabupaten Jember dapat ditarik kesimpulan sebagai berikut:

1. Motivasi belajar siswa yang menggunakan metode permainan kartu bilangan pada pembelajaran materi pecahan lebih tinggi daripada pembelajaran yang tidak menggunakan metode permainan kartu bilangan.

2. Hasil belajar siswa yang menggunakan metode permainan kartu bilangan pada pembelajaran materi pecahan lebih baik daripada siswa yang tidak menggunakan metode permainan kartu bilangan.

Untuk pembelajaran dengan menggunakan metode permainan kartu bilangan ini hendaknya harus disiapkan sejumlah set kartu bilangan sesuai dengan kelompok yang akan dibentuk agar waktu pembelajaran benar-benar bisa dimanfaatkan secara efektif dan efisien.

Dalam penerapan konsep yang baru hendaknya peneliti terjun langsung sebagai pengajar sehingga bisa berbaur dengan siswa dan lebih mengetahui kendala-kendala yang dihadapi siswa dalam pembelajaran pada materi yang disampaikan.

\section{Rujukan}

Ainurrahman. 2009. Strategi Dalam Pembelajaran. Jakarta: CV. Pustaka Ilmu.

Aman, S. 1985. Pedoman Metode Penyajian Pendidikan Moral Pancasila danPenerapannya. Jakarta: Depdikbud. 
Dwiana, Deni., dkk. 2011. Penggunaan Metode Permainan Kartu Bilangan Untuk Meningkatkan Pembelajaran Matematika Tentang Pecahan. Diakses dari file:///E:/Jurnal/567-1437-1PB.pdf. Pada tanggal 13/11/ 2017

Hudoyo, H. 2005. Kapita Selekta Pembelajaran Matematika. Malang: Universitas Negeri Malang.

Sagala, S. 2010. Konsep dan Makna Pendidikan. Bandung: Alfabeta.

Sanjaya, Wina. 2011. Strategi Pembelajaran Berorientasi Standar Proses Pendidikan. Jakarta: Kencana

Zaelani, A.S. 2011. Pembelajaran Konsep Pecahan Senilai di SD melalui Permainan Model Kartu Domino Pecahan (Kado-Pecah). Diakses dari http://sman1palu.org/index.php/comp onent/content/article/120-pembelajarankonsep-pecahan-senilai-di-sdmelalui-permainan-model-kartu-domino-pecahan-kadopecah.html pada tanggal 13/11/2017. 